\title{
接触照射によるレーザ一前立腺手術
}

\author{
野垣譲二 青木 豊 烊田清己 \\ 日本大学医学部泌尿器科学教室
}

\section{LASER SURGERY for BPH by CONTACT IRRADIATION}

Joji NOGAKI, Yutaka AOKI and Kiyoki OKADA

Department of Urology, Nihon University School of Medicine

Nd:YAG laser has high penetrating rate to the tissue, and it is possible to vaporize the tissue, efficiently. Taking advantages of these characters of the Nd:YAG laser, we carried out transurethral laser surgery for benign prostatic hyperplasia by method of contact irradiation in 57 cases between April 1993 and August 1994. Forty-nine cases of them were without other adjuvant therapies.

Patients' age ranged 53-85 years old (ave.69). The results of preoperative examinations were as follows: AUA-Prostate Symptom Score (AUA-PSS) was 15-32 points (ave.21), maximum flow rate (Qmax) 0.4-14.4 ml/sec(ave.6.25), and average flow rate $0.4-9.8 \mathrm{ml} / \mathrm{sec}$. (ave.3.7).

In all cases, the prostatic tissue was evaporated by contact irradiation method at over 50 watts output. No bleeding was found during and after the operation. Total amount of irradiation was 1700-117030 joules (ave.26235), operation time 15-105 minutes(ave.46.6). The results of postoperative examinations were as follows: AUA-PSS of 4-26points (ave.11), maximum flow rate(Qmax) $2.9-29 \mathrm{ml} / \mathrm{sec}$. and average flow rate $1.8-18.4 \mathrm{ml} / \mathrm{sec}$.(ave.9.0).

There were 18 cases with transitory urinary retention when catheters were removed 3-5days after the operation. Acute epididymitis was found in 3 cases. Now we are researching the long term results of 1 year follow up, postopeatively.

\section{1.緒言}

Nd:YAGレーザーは組織内への透過性が高く、 組織蒸散能に俱れている。当教室ではこのNd :YAGレーザーの組織蒸散效果を最大限に生か すため、接触照射が可能な侧射用ファイバー (UItraLine ${ }^{T M}$ )を用いて前立腺肥大症に対す
る経尿道的レーザー手術(Transurethral Las er Surgery of Prostate:TULS-P)を行なって いる。組稢に接触させてレーザー光を照射す ることによって蒸散效率は著しく大きいすの になり、短時闍で前立腺にcrater状の欠損を 生し、しかもその周团組織は疑固坟死となり 
脱落し、殆ど出血を見ることなしに排尿障害 が改善することができる。

\section{2. 対象}

1993年4月～1994年8月の間に日本大学板檴 病院にて57例のレーザー前立腺手術を実施し た。このうち 8 例は他の治療法を作用してい るためレーザー前立腺手術(TULS-P) 単独の49 例を対象とした。年粭は53才から85才(平均6 9.3才)であった。これより先、患者選択基準 として

a. 50 才以上の排尿障害を訴元る前立腺肥大症 の患者

b. AUA Symptom Score 15点以上

c. 最大尿流率 $15 \mathrm{ml} / \mathrm{sec}$. 以下

d. 前立腺推定体樻 $20 \mathrm{~m} 1$ 以上

e. 他に排尿障害をきたす族患の合併のない とした。

\section{3. 方法}

\section{1) 動物実駼}

臨床例に先立ち成犬 7 匹を使用して経膀胱 瘦的にレーザー前立腺手術を行ない、その効 果と安全性を梌索した。50W30秒の固定照射 で $5 \mathrm{~mm}$ のcrater と 3 m喵壊死周が碓認され、 レーザーの梁達度としては 8 吅であり、広箱 囲に照射することによって尿道前立娦部のca vitationが得られ、6週間後の所見では移行 上皮の再生が確認された。

2) 使用譏器

Nd:YAGレーザー発生装置としてLaserSonic s社製Model 6000あるいは同社のHercules 50 60Uを使用し、導光路のファイバーとしてLas erSonics社製UltraLineを使用した。このUlt raLineは石英ファイバーの先端のカット面に
生ずるプリズム効果によってファイバー内の レーザー光を㒋方へ $80^{\circ}$ 屈曲させており、金 哃リフレクターを使用していないため、組織 に接触させて照射することが可能である。内 視鏡は一般に使用されている尿道膀胱鏡を使 用した。

3)手術

腰椎麻酔下磁石位として超音波ガイド下で 経直腸的前立腺針生検を実施した後テレビモ ニター下で鈿察しながら従来のTUR-Pと同様 に内視鏡的に手術を行なった。 $50 W$ ，30秒を 1 単位として接触照射を中心に内視鏡的に2 時, 4 時, 8 時, 10 時の位置に照射した。接触し た上で固定照射と移動照射の $2 つ の$ 照射手技 を採用した。

4) 㭘討項目

治療前後でAUA-Symptom Score, 最大㲾流率 $(Q \max$.$) ，平均尿流率(average flow rate), 残$ 尿舅を测定した。治療後については㙥死層が 脱落し、新しい移行上皮が再生してくる術後 $6 \sim 8$ 週間後、および 6 カ月後、 1 年後で上 記項目につき評価を下した。また経直腸的前 立腺超音波検查(TRUS)，前立腺体䅡，尿道膀胱 造影については術後には多くの症例では実施 できないものが多く、参考項目とした。カテ 一テルの抜去洔期および術後の入院期間につ いてついては全例記载した。

\section{4. 結果}

49例のTULS-Pを实施した。手術時間は最短 15分最長105分で平均50.4 土21.4分, Nd:YAG Laserの照射量は1700〜117030jouleで平均36 $331 \pm 24623$ jouleという結果であった。 評価項目としてはAUA-Sympyom Scoreでは 
術前平均21.6点が術後6-8週で11.2点と改善 し、 1 年後 $(12$ 例)では9.6点とさらに改盖を 示した(図1)。

図1

AUA SYMPTOM SCORE

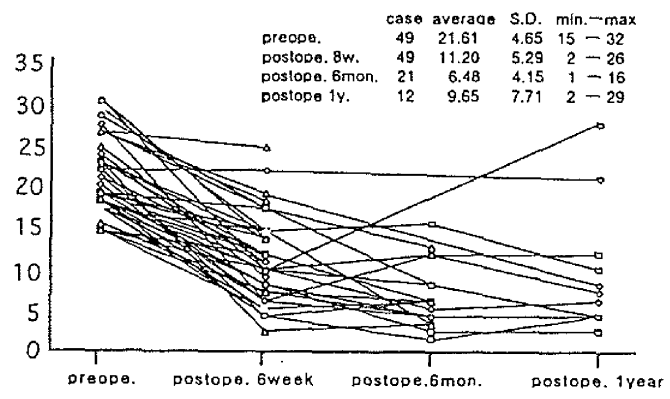

最大尿流率 ( Q max.) では術前平均 $6.3 \mathrm{ml} / \mathrm{sec}$. であったものが術後6-8週で13.7ml/sec.1年 後 $15.1 \mathrm{ml} / \mathrm{sec}$.であった(図2)。平均尿流率(a verage flow rate) では術前平均 $3.7 \mathrm{ml} / \mathrm{sec}$. から $8.9 \mathrm{ml} / \mathrm{sec}$. (術後6-8週)，10.1ml/sec.( 術後1年11例)であった。残尿量は術前平均11

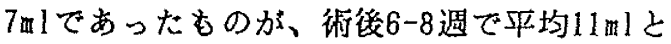
改善を示した。症状スコアの上でも客钼的評 価からす排尿障害の改善を示し、また 1 年経 過後むその効果は充分に維持された。

\section{最大尿流率( $\mathrm{m} / \mathrm{sec}$ ) 図2}

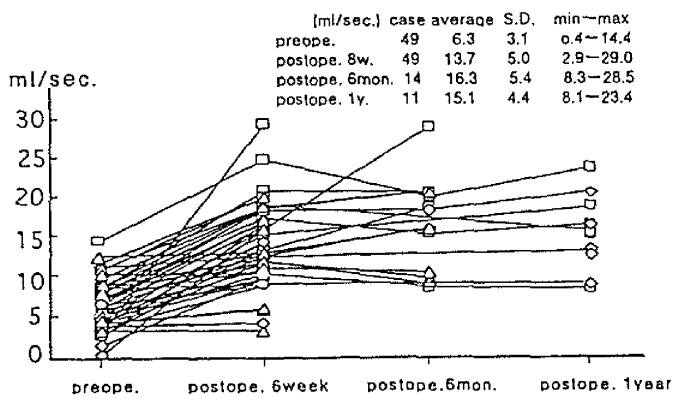

副作用については 3 例に急性精巣上体炎を 認めた。また、照射部位の浮腫による一過性 の尿閣が19例に出現したが洔間の経過ととも に改善した。術中出血は殆ど琶めず、第孔例
むなく、低Na血症や他の術後合併症も認めな かった。たたし、術後 1 週間以上経過してか ら後出欰として肉眼的血尿が生じたものが 2 例存在した。そのうち 1 例はワーファリン内 服中の症例であった。

\section{5. 考察}

1) 接触照射 Contact Irradiation

最近出現してきたレーザー前立腺手術の多 くは非接触照射による組織の凝圆坮死を目的 としたもの多い。非接触照射法 Non-contact Irradoationではレーザーの光のエネルギー が組織に到達するまでに距難があり、組織を 通過し熱のエネルギーに変換されるまでに散 乱、反射によって大きなロスが生じる。従っ て同じ出力で照射しても充分な蒸散効果は得 られにくく、肉眼的には白色变性という反応 が起こる。これは組織学的には凝固壊死であ る。盗死組䋘はやがて脱落し、cavitationが 生じ、約 6 週間後には新たな尿道上皮が再生 される。一方、接触照射法 Contact Irradia tionではレーザーの光のエネルギーが組織内 に熱のエネルギーとして效率良く伝わり、組 織は短時間のうちに蒸散され、crater状の大 きな組織欠損が生じる。そして、その周四の 白色变性した部位は凝固流死に陷る。徒って、 尿道前立腺部全域に照射しなくても拡㖘した 平滑な粘膜面が得られる。また、50Wの出力 で接触照射を行なうと急速に気泡が発生して 瞬く間に空洞が形成されていくのが観察され る。これを扣速蒸散現象(Acceralated Evapo ration Phenomenon:AEP)という。この接触照 射の方が非接触照射より治療效碎が高く、内 視鏡直視下での治痖にはふさわしい照射法と 
考えられた。

2)照射手技

固定照射Spot Irradiation はレーザーファ イバーを動かさずに 1 力所に固定して、それ を数っ所にわたり照射する方法であるが、全 く動かさないとレーザーの特性である直進性 と平行性が忠実に嚴守され、レーザー光が拡 がることなく、どんどん梁部に蒸散が起こり、 穿孔をおこす。従って臨床例では固定照射と いえどもわずかにレーザー光をスイングさせ て拡散させる要領で実施すると広く大きな aterが形成される。固定照射の場合は原則と して 1 っ所に対して50W30秒(1500joule)ま でとした。

移動照射Running Irradiationは膀胱頸部 から遠位方向にレーザー光を移動させながら 照射する手技で50Wで60〜90秒かけて精皁付 近までファイバーを引いてくる方法である。 前立腺組織が蒸散されて梁い攞を形成される のが観察される。固定照射よりやや浅い組緎

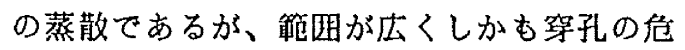
险性が低い。凝固境死紧の範明も広く術後の cavitationの形状についてむ固定照射による ものよりさらに広く、平滑なものとなり、臨 床的有用度の高い照射法と言える。ただし、 術後の浮腫の発現が圆定照射よりやや著しい 倾向にある。

3) T UR - Pとの比較

1990年1月から1993年6月の間に当教窒でお こなった電気メスによる通常のTUR-P120例と 比較するとこのTULS-Pの安全性を確認するこ とができる(表1)。一方、有効性については TUR-P群において症状のScoringや尿流湘定が
充分に実施されていなかったため比較はでき なかった。しかし、TULS-Pの症状Score改善 度や客钼的データーの改善からTUR-Pに遴色 のない成羅であったと推测される。以上より TULS-Pは今後前立腺肥大症の第 1 選択の治療 法となりうることが期待される。

表1 TULS-P, TUR-Pの術中術後合作症·副作用

\begin{tabular}{|c|c|c|}
\hline 術中合作症 & T UL S-P & TUR-P \\
\hline 血 & O例 & 16 例 (13.3\%) \\
\hline 血圧低下 & O例 & 10 例 $(8.3 \%)$ \\
\hline 孔 & 0 例 & 3 例 $(2.5 \%)$ \\
\hline 低 $\mathrm{Na}$ Ifll症 & O例 & 8 例 $(6.7 \%)$ \\
\hline TUR症候群 & O 例 & 2 例 $(1.7 \%)$ \\
\hline
\end{tabular}

\begin{tabular}{ccc} 
術後合作症 & TULS-P & T UR-P \\
\hline 後 出 1 血 & 2例 $(4.1 \%)$ & 20 例 $(16.6 \%)$
\end{tabular} 尿道狭窄 0 例 2 例( $1.7 \%)$ 精紧上体炎 3 例 $(6.1 \%) \quad 2$ 例 $(1.7 \%)$ 尿失禁 0 例 2 例 $(1.7 \%)$

\section{6 . 結謤}

1)前立腺肥大症57例に対して接触照射による レーザー手術を実施した。

2)自他覚的に排尿障害の改善を認め、その訤 果は手術 1 年程過後も充分に維持された。

3)接触照射法は組織の蒸散効果が大きく、移 動照射することにより安全性む高く、有用 な治噔法であると考えられた。

4)術中術後もほとんど出血は諗められないが、 術㨁後は浮腫による一過性の排永障害が存 在した。 